\title{
Research on risk factors analysis of tunneling through bridge using active underpinning technology
}

\author{
WANG Lin ${ }^{1, a}$, Li Xiaozhong ${ }^{1, b}$, BAO Xueying ${ }^{1, c}, Z H O U ~ S h i-j u n^{2, d}$ \\ ${ }^{1}$ School of Civil Engineering, Lanzhou jiaotong University, lanzhou 730070 ,China; \\ ${ }^{2}$ School of Civil Engineering, Chongqing University, Chongqing 400030, China

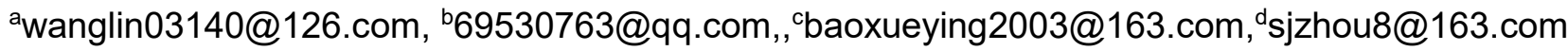

\begin{abstract}
Keywords: active underpinning technology; tunneling through bridge; risk factors analysis; interpretive structural model(ISM)

Abstract. In order to effectively manage the construction risk of tunnel crossing existing bridge projects with active underpinning technology, the relations of risk factors were analyzed using interpretive structural mode. Used WBS - RBS method to identify all risk factors, established the risk factors adjacency matrix, calculated and divided the reachability matrix. The risk factors of tunneling through existing bridge using active underpinning technology were classified into nine levels. Through analyzing the relations of nine levels, clarified the relationship between risk factors, made recommendations for project risk management, suggested benefits for dynamic risk management of the project.
\end{abstract}

\section{Introduction}

With the rapid development of urban rail transit, many urban rail projects are limited by time and space, so they need to cross the bridge at close range or cross the bridge pier directly. The excavation of the tunnel will disturb the foundation of the bridge. In order to guarantee the stability and safety of existing bridges, it will adopt the construction of the pile foundation active underpinning technology. Active underpinning technology is a new highly comprehensive special construction technology, construction difficulty, high cost, long construction period, construction process of survey, design, construction organization, monitoring and control is very demanding. In addition, both the structure form, load size, deformation control requirements, the construction space, in field situation and wear the requirement of structure under different determines the active underpinning engineering significant individual difference. These factors make the construction of these kind of projects become more difficulty, higher requirements of the enterprise management level of construction technology.In order to meet the requirement of project construction under high risk, it is necessary to carry out risk research on the bridge project under the tunnel under the active underpinning technology.

At present, there are few risk analysis of tunnel underpassing and underpinning technologies. $\mathrm{Bu}$ Jian-qing has identified some risk factors in the construction process ${ }^{[1]}$. Jiang Xiao-rui, Jia Xiao-bo adopts the expert survey method to carry out qualitative risk identification and evaluation of intercity rail crossing high-speed bridge project from the design stage ${ }^{[2]}$. Chen Jiejin and Zhang Yongjie used fuzzy fault tree and analytic hierarchy process to quantitatively analyze the deformation damage of Guangfu flyover ${ }^{[3]}$. CUI Yang-hua The deformation and force of bridge piles before and after the cutting and excavation of urban roads were compared by finite element analysis, and the construction safety status of bridges under the existing underpass rail transit projects was evaluated ${ }^{[4]}$. Lin Zhen uses accident tree analysis method to quantitatively analyze the risk of bridge instability and damage $^{[5]}$.These researches are all based on the recognition and evaluation of the risk of the tunnel under the existing bridge or underpinning technology based on certain aspects. There is no systematic identification and analysis of risk factors and no analysis of the relationship between risk factors. In this paper, under the background of the Guan-Hui Inter-city Bridge under the Guangshen Expressway, the relationship between the risk factors in the construction process of the project is analyzed by 
interpreting the structural model, which is helpful to identify the key risk factors during the construction of the project and provide the dynamic risk management work to provide the basis.

\section{The Project Background}

Dongguan to Huizhou intercity track Songshanhu tunnel Daojiao $\sim$ Dongguan New Town interval DK10 +260 DK10 +300 section of the Guangzhou-Shenzhen Expressway Dongguan North Bridge $\mathrm{N}$ bridge dry pier N76, N77 through between the viaduct N77-D1 pile Basement intrusion into the main structure of the tunnel side of the tunnel, the intrusion distance of about $0.29 \mathrm{~m}$, the rest of the pile under the N77 piers and N76 pier under the tunnel construction within the scope of influence, from the tunnel nearest bridge pile N76-A, and the tunnel The horizontal clearance is $2.067 \mathrm{~m}$. The tunnel is a single-story, double-deck, rectangular frame with a total width of $15.2 \mathrm{~m}$ and a total height of $8.815 \mathrm{~m}$. The tunnel clearance is $6.55 \mathrm{~m}$ per hole and $7.115 \mathrm{~m}$ high. The construction of Mingzhu Shun construction method, the foundation pit retaining structure using $11000 @ 1200, \Phi 1200 @$ 1350 bored piles + internal support support. The upper part of the dry bridge 13 of the Guangzhou-Shenzhen high-speed Baima River Bridge is constructed of a continuous prestressed concrete T-beam with a span of $32.5 \mathrm{~m}$, which is supported by a simple supported bridge deck. The lower bridge piers are $1.2 \mathrm{~m} \times 1.0 \mathrm{~m}(\mathrm{~N} 76), 1.2 \mathrm{~m} \times 1.2 \mathrm{~m}(\mathrm{~N} 77)$ square double column piers, all of which are end piles. Guangzhou-Shenzhen high-speed White Horse River Bridge was completed in 1995, the tunnel construction process, the normal use of the bridge.

\section{Identification of Risk Factors for tunneling through bridge projects with Active Underpinning Technology}

The tunnel crossing existing bridge projects with active underpinning is a very complicated system project. The environment of the project is complex and it has higher requirements on construction monitoring, construction operation and organization management, and the risks are also greater. Therefore, the construction risk factors using the method of work decomposition and risk decomposition structure to identify the combination of methods. The work breakdown of the project is shown in Figure 1, and the risk decomposition structure is shown in Figure 2. The identified risk factors are shown in Table 1. 


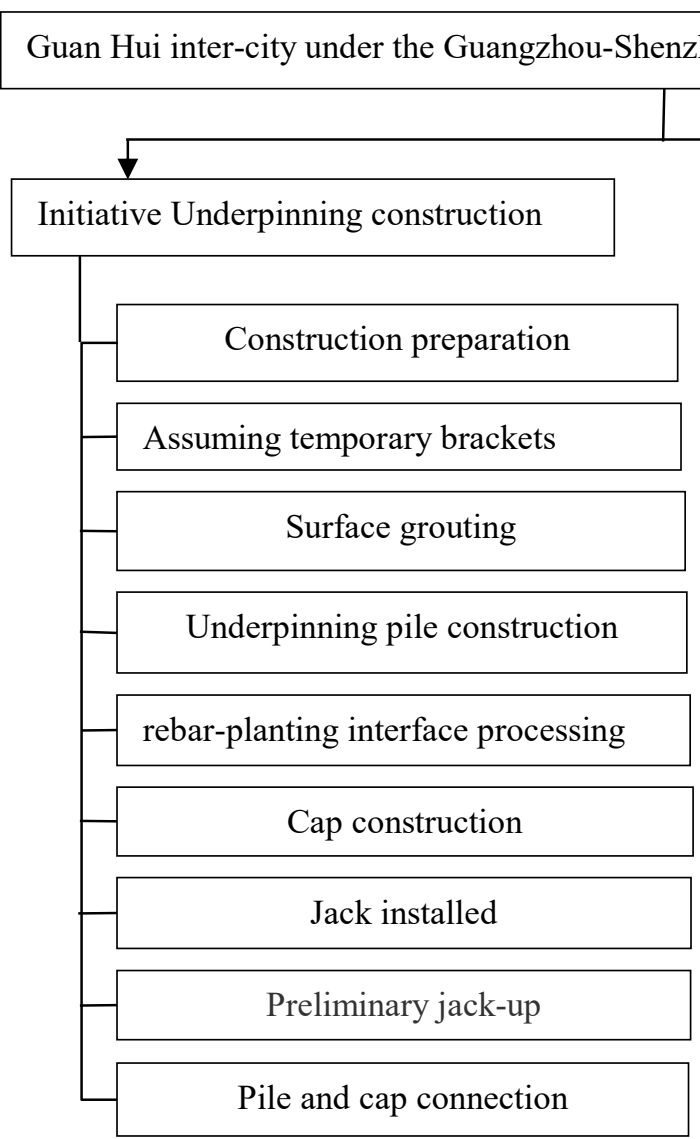

Fig.1 WBS of tunneling through existing bridge

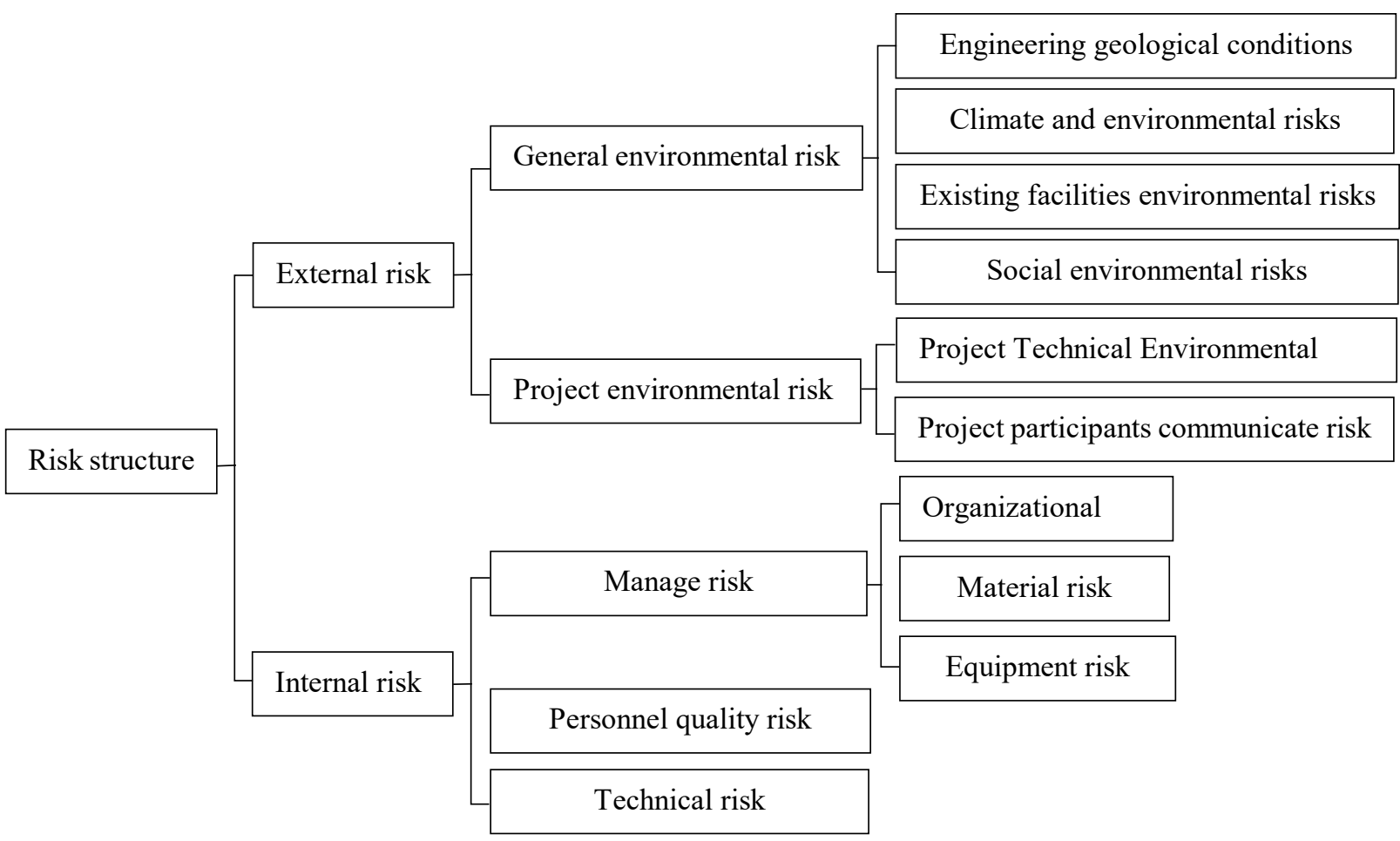

Fig.2 RBS of tunneling through existing bridge 
Tab.1 Risk factors of tunneling through existing bridge

\begin{tabular}{|c|c|c|}
\hline Risk factors & $\begin{array}{l}\text { Risk } \\
\text { num } \\
\text { ber }\end{array}$ & Judgment basis \\
\hline $\begin{array}{l}\text { Bad geological } \\
\text { conditions }\end{array}$ & $\mathrm{R}_{1}$ & $\begin{array}{l}\text { There are many types of soil site, and the widely distributed saturated sands in the site } \\
\text { are rich in groundwater, it's structure is loose and easily collapsed during construction } \\
\text { excavation. The saturated silt layer is locally liquefied earth. The site is basically } \\
\text { muddy silty clay, and with soft structure, low carrying capacity, low shear strength, } \\
\text { high compressibility, poor water permeability, odor. Generally distributed weathered } \\
\text { rocks are muddy siltstone, gravel sandstone, core is earthy, and with Lower bearing } \\
\text { capacity, lower shear strength, medium compressibility, poor water permeability, easy } \\
\text { to soften water, collapse. Engineering geological conditions are poor, prone to safety } \\
\text { risk accidents. }\end{array}$ \\
\hline Adverse climate & $\mathrm{R}_{2}$ & $\begin{array}{l}\text { The project area belongs to the tropical monsoon climate. No cold in winter, hot and } \\
\text { humid in summer, more thunderstorms, typhoon and torrential rain are the main } \\
\text { catastrophic weather. In addition, unfavorable weather conditions such as high } \\
\text { temperature, heavy fog and rainy season will also bring risks to the project } \\
\text { construction. }\end{array}$ \\
\hline Earthquake & $\mathrm{R}_{3}$ & $\begin{array}{l}\text { According to the "Zoning Map of Ground Motion Parameters of China" } \\
\text { (GB18306-2015), seismic fortification intensity in the project area is VII, } \\
\text { consideration should be given to the possible adverse impact of the earthquake on the } \\
\text { project }\end{array}$ \\
\hline $\begin{array}{l}\text { Unreasonable } \\
\text { design }\end{array}$ & $\mathrm{R}_{4}$ & $\begin{array}{l}\text { Inaccurate geological survey data may lead to unreasonable program design; } \\
\text { unreasonable design including the design of bored piles in enclosures, enclosures, } \\
\text { support structure design and underpinning structural design, etc., may result in waste } \\
\text { or unsafe the superstructure. }\end{array}$ \\
\hline $\begin{array}{l}\text { Communicate } \\
\text { risk of project } \\
\text { parties }\end{array}$ & $\mathrm{R}_{5}$ & $\begin{array}{l}\text { Project owners, design units, testing units, construction units and other participants } \\
\text { with poor communication of information, or delays in the decision-making due to time } \\
\text { delay, investment overruns and other risks. }\end{array}$ \\
\hline $\begin{array}{l}\text { Stake } \\
\text { construction risk }\end{array}$ & $\mathrm{R}_{6}$ & $\begin{array}{l}\text { Reinforcement risk owing to the undesirable stake material; excessive lateral } \\
\text { squeezing pressure to the piles owing to the unreasonable construction sequence of } \\
\text { stake. }\end{array}$ \\
\hline $\begin{array}{l}\text { Quality risk of } \\
\text { temporary stent } \\
\text { expansion } \\
\text { foundation }\end{array}$ & $\mathrm{R}_{7}$ & $\begin{array}{l}\text { Due to the material does not meet the requirements, or the undesirable template } \\
\text { construction and concrete pouring cause the undesirable strength of temporary stent } \\
\text { expansion e foundation }\end{array}$ \\
\hline $\begin{array}{l}\text { Instability of } \\
\text { Bere Beam }\end{array}$ & $\mathrm{R}_{8}$ & $\begin{array}{l}\text { Risk with foundation instability or not erected as required or disqualification of } \\
\text { scaffold material and others. }\end{array}$ \\
\hline $\begin{array}{l}\text { Steel box beam } \\
\text { with poor quality }\end{array}$ & $\mathrm{R}_{9}$ & $\begin{array}{l}\text { Steel box beam with poor quality, will result in temporary bearing capacity does not } \\
\text { meet the requirements, affecting the safety of the bridge structure }\end{array}$ \\
\hline $\begin{array}{l}\text { Lifting transport } \\
\text { risk of steel box } \\
\text { girder }\end{array}$ & $\mathrm{R}_{10}$ & $\begin{array}{l}\text { During the hoisting process of steel box girder, the operation of the crane was } \\
\text { incorrect, the operation route was unreasonable, and the lifting speed was too fast, } \\
\text { which led to the impact and collision of the beam body. }\end{array}$ \\
\hline $\begin{array}{l}\text { Drilling piles } \\
\text { construction risk }\end{array}$ & $\mathrm{R}_{11}$ & $\begin{array}{l}\text { In the process of construction, collapsible holes, broken drill pipe, skewed drilling } \\
\text { holes, water inflow, reaming or shrinkage holes, deflection of steel cage, and elevation } \\
\text { of reinforced cage may not meet the requirements.etc.. }\end{array}$ \\
\hline $\begin{array}{l}\text { Surface grouting } \\
\text { parameters are } \\
\text { inappropriate }\end{array}$ & $\mathrm{R}_{12}$ & $\begin{array}{l}\text { Grouting range, depth and other parameters with wrong choice, may not achieve the } \\
\text { desired reinforcement effect. }\end{array}$ \\
\hline $\begin{array}{l}\text { Drilling grouting } \\
\text { construction risk }\end{array}$ & $\mathrm{R}_{13}$ & $\begin{array}{l}\text { Cement quality failed, or not according to the provisions of the slurry ratio } \\
\text { measurement; drilling position deviation, drilling depth and other reasons lead to } \\
\text { quality defects; grouting drilling errors, drilling direction deviation, string pulp and } \\
\text { other conditions lead to the bad influences of bridge structure. }\end{array}$ \\
\hline $\begin{array}{l}\text { Artificial hollow } \\
\text { cast-in-place pile } \\
\text { construction risk }\end{array}$ & $\mathrm{R}_{14}$ & $\begin{array}{l}\text { Artificial hollow cast-in-place pile construction process may cause collapse, object hit } \\
\text { accident, fall accident and poisoning suffocation accident,etc.. }\end{array}$ \\
\hline $\begin{array}{l}\text { Undesirable } \\
\text { bearing capacity }\end{array}$ & $\mathrm{R}_{15}$ & $\begin{array}{l}\text { Risk Because the verticality of the underpinning pile does not meet the requirements, } \\
\text { the pile diameter does not meet the requirements, the thickness of the bottom of the }\end{array}$ \\
\hline
\end{tabular}




\begin{tabular}{|c|c|c|}
\hline $\begin{array}{l}\text { of Underpinning } \\
\text { pile }\end{array}$ & & $\begin{array}{l}\text { nderpinning pile hole sediment exceeds the limit, the depth of the underpinning pile } \\
\text { ole is insufficient, the quality of the underpinning concrete pile is problematic. }\end{array}$ \\
\hline $\begin{array}{l}\text { Cap } \\
\text { risk }\end{array}$ & $\mathrm{R}_{16}$ & $\begin{array}{l}\text { Prestressed construction, in the process of tensioning due to construction, materials } \\
\text { and other possible accidents; Prestressed lack of tension; cracks produce by } \\
\text { incautiously construction in the joint processing of large-volume concrete pouring, } \\
\text { affecting the overall bearing capacity and durability of the cap, construction vibrations } \\
\text { can also adversely affect the bridge structure. }\end{array}$ \\
\hline $\begin{array}{l}\text { risk caused by } \\
\text { New platform } \\
\text { and the original } \\
\text { pier }\end{array}$ & $\mathrm{R}_{17}$ & $\begin{array}{l}\text { Due to the unreasonable construction of planting hole drilling or tapping mouth, or the } \\
\text { lack of cohesion of new and old concrete at consolidation point or the unreasonable } \\
\text { construction temperature, the load carrying capacity of nodes will affect the risk of } \\
\text { bridge safety. }\end{array}$ \\
\hline $\begin{array}{l}\text { Insta } \\
\text { of Ja } \\
\text { pad }\end{array}$ & $\mathrm{R}_{18}$ & $\begin{array}{l}\text { Jack, pipe spacer safety device set the time and location, steel pipe pad safety device of } \\
\text { the flatness, strength, stiffness and stability under load, etc. for the initiative } \\
\text { underpinning construction technology is a very important aspect, any one aspects do } \\
\text { not meet the requirements of the consequences are very serious. }\end{array}$ \\
\hline Jack & $\mathrm{R}_{19}$ & $\begin{array}{l}\text { Each care pile jack load unsynchronized or load distribution is unreasonable or over } \\
\text { load is too small lesd to the care structure and line unreasonable stress, stress } \\
\text { displacement does not meet the requirements, etc .; besides, jack failure can not be } \\
\text { sustained load, can not be normal Provide pressure, can not adjust timely when the pier } \\
\text { appears settlement, and jack pressure anomaly, may cause the risk of inaccurate } \\
\text { calculation of the pier actual load. }\end{array}$ \\
\hline $\begin{array}{l}\text { Jack } \\
\text { syste }\end{array}$ & $\mathrm{R}_{20}$ & $\begin{array}{l}\text { ure and other reasons caused jacking control } \\
\text { ult in pier settlement; may also result in monitoring }\end{array}$ \\
\hline $\begin{array}{l}\text { Brid } \\
\text { cutti }\end{array}$ & $R_{21}$ & pile; \\
\hline $\begin{array}{l}\text { Grou } \\
\text { jet g1 }\end{array}$ & $\mathrm{R}_{22}$ & nd uplift and \\
\hline $\begin{array}{l}\text { Earthwork } \\
\text { excavation } \mathrm{r}\end{array}$ & $\mathrm{R}_{23}$ & f deep soil \\
\hline $\begin{array}{l}\text { Unf } \\
\text { sup } \\
\text { fou }\end{array}$ & $\mathrm{R}_{24}$ & $\begin{array}{l}\text { too large, } \\
\text { ting the }\end{array}$ \\
\hline of & $\mathrm{R}_{25}$ & ce subsidence, \\
\hline $\begin{array}{l}\text { ructure } \\
\text { ction risk }\end{array}$ & $\mathrm{R}_{26}$ & struction \\
\hline $\begin{array}{l}\text { Risk of collision } \\
\text { between } \\
\text { construction } \\
\text { machinery and }\end{array}$ & $\mathrm{R}_{27}$ & construction may \\
\hline Con & $\mathrm{R}_{28}$ & $\begin{array}{l}\text { ring } \\
\text { tion, risk } \\
\text { r, etc.. }\end{array}$ \\
\hline ity & $\mathrm{R}_{29}$ & d risk \\
\hline $\begin{array}{l}\text { Risk of on-site } \\
\text { organization and } \\
\text { management }\end{array}$ & $\mathrm{R}_{30}$ & $\begin{array}{l}\text { Due to the adverse organization and management of the site, various risk accidents } \\
\text { such as electrical safety accidents, mechanical operation accidents and fires, etc., and } \\
\text { the poor supply of raw materials, construction equipment and power due to adverse } \\
\text { organizational management, will affect the time. A sudden power outage can result in } \\
\text { an interruption of control of the jacking up computer system that could cause the pier } \\
\text { to settle; it may also cause the monitoring to be delayed. } \\
\text { Project owners, design units, testing units, construction units and other participants } \\
\text { with poor communication of information, or delays in the decision-making due to time } \\
\text { delay, investment overruns and other risks. }\end{array}$ \\
\hline $\begin{array}{l}\text { Pers } \\
\text { risk }\end{array}$ & $\mathrm{R}_{31}$ & $\begin{array}{l}\text { Risk because the technical interview is not in place, the technical level is insuffic } \\
\text { the operation is wrong, the personnel on site do not perform their duties }\end{array}$ \\
\hline
\end{tabular}




\begin{tabular}{l|l|l}
\hline $\begin{array}{l}\text { Construction } \\
\text { machinery injury } \\
\text { risk }\end{array}$ & $\mathrm{R}_{32}$ & $\begin{array}{l}\text { Possible accidental injury of structure and personnel caused by construction } \\
\text { machinery. }\end{array}$ \\
\hline Time risk & $\mathrm{R}_{33}$ & Duration extension risk in the process of project construction. \\
\hline Security Risk & $\mathrm{R}_{34}$ & $\begin{array}{l}\text { Risk of personnel safety, structural safety, third-party safety in the process of project } \\
\text { construction. }\end{array}$ \\
\hline $\begin{array}{l}\text { Environmental } \\
\text { risk }\end{array}$ & $\mathrm{R}_{35}$ & $\begin{array}{l}\text { Tunnel under the existing bridge construction project on the surrounding environment } \\
\text { is mainly reflected in the impact on existing bridges, the project will inevitably lead to } \\
\text { the construction of the bridge subsidence, offset or tilt, when the bridge foundation or } \\
\text { any part of the superstructure exceeds the limit of carrying capacity status or normal } \\
\text { use of the limit state, can have very serious consequences. }\end{array}$ \\
\hline investment risk & $\mathrm{R}_{36}$ & \begin{tabular}{l} 
Investment increases risk in the process of project construction. \\
\hline
\end{tabular} \\
\hline
\end{tabular}

\section{The establishment of interpretive structure model(ISM)}

Establish the adjacency matrix for structural relationship of risk factors ${ }^{[6]}$.

Make a judgement of the relationship between the identified risk factors of tunnel crossing existing bridge projects with active underpinning technology, the adjacency matrix A was established as shown in Table 2.

$a_{i j}$ is the element of the matrix A, it is defined as the formula (2).

$$
\alpha_{t j}=\left\{\begin{array}{c}
1, \quad \text { When there is a relationsh ip between } \mathrm{R}_{\mathrm{i}} \text { and } \mathrm{R}_{\mathrm{j}} \\
0, \quad \text { When there is no relationsh ip between } \mathrm{R}_{\mathrm{i}} \text { and } \mathrm{R}_{\mathrm{j}}
\end{array}\right.
$$

Solving the reachability matrix $M$.

The definition of the element mij in reachability matrix $M$ is shown in formula (3).

$$
\mathrm{m}_{\mathrm{ij}}=\left\{\begin{array}{l}
1, \quad \text { There is a way from } R_{\mathrm{i}} \text { to } R_{j} \\
0,
\end{array}\right.
$$

According to table 2, the reachability matrix $\mathrm{M}$ of the adjacency matrix A can be obtained by using Boolean algebra operation, as shown in Table 3.

Hierarchical division of reachability matrix.

The elements aggregation which is influenced by $R_{i}$ was defined as a reachability set $S\left(R_{i}\right)$ of $R_{i}$; The aggregation of influencing factors was defined as $R_{i}$ 's antecedent set $A\left(R_{i}\right)$; Underlying element set $B=\left\{R_{i} \mid S\left(R_{i}\right) I A\left(R_{i}\right)=A\left(R_{i}\right)\right\}$,if $R\left(r_{i}\right) I A\left(r_{i}\right)=R\left(r_{i}\right)$, then it is the most advanced element.

Searching for the most advanced element at all levels, according to the reachability matrix, $S\left(R_{i}\right) 、 A\left(R_{i}\right) 、 R\left(r_{i}\right)$ I $A\left(r_{i}\right)$ of each element can be obtained, marking off the elements in $\mathrm{L}_{1}$ from the reachability matrix; The most advanced factor set of second level $\mathrm{L}_{2}$ is determined according to the same method. By analogy, up to obtaining the bottom factor set $\mathrm{L}_{n}$. In this way, risk factors can be divided into different levels.

With the help of Matlab2010, nine levels $\mathrm{L}_{1} \sim \mathrm{L}_{9}$ of the risk factors in the tunnel crossing the bridge project with active underpinning technology can be obtained, as shown in table 4 . 
Tab.2 Adjacency matrix A

\begin{tabular}{|c|c|c|c|c|c|c|c|c|c|c|c|c|c|c|c|c|c|c|c|c|c|c|c|c|c|c|c|c|c|c|c|c|c|c|c|c|}
\hline & $R_{1}$ & $R_{2}$ & $\mathrm{R}_{3}$ & $\mathrm{R}_{4}$ & $\mathrm{R}_{5}$ & $\mathrm{R}_{6}$ & $\mathrm{R}_{7}$ & $\mathrm{R}_{8}$ & $\mathrm{R}_{9}$ & $\mathrm{R}_{10}$ & $\mathrm{R}_{11}$ & $R_{12}$ & $\mathrm{R}_{13}$ & $\mathrm{R}_{14}$ & $\mathrm{R}_{15}$ & $\mathrm{R}_{16}$ & $R_{17}$ & $\mathrm{R}_{18}$ & $R_{19}$ & $\mathrm{R}_{20}$ & $\mathrm{R}_{21}$ & $\mathrm{R}_{22}$ & $\mathrm{R}_{23}$ & $\mathrm{R}_{24}$ & $\mathrm{R}_{25}$ & $\mathrm{R}_{26}$ & $\mathrm{R}_{27}$ & $R_{28}$ & $\mathrm{R}_{29}$ & $\mathrm{R}_{30}$ & $R_{31}$ & $\mathrm{R}_{32}$ & $\mathrm{R}_{33}$ & $\mathrm{R}_{34}$ & $\mathrm{R}_{35}$ & $\mathrm{R}_{36}$ \\
\hline $\mathrm{R}_{1}$ & 0 & 0 & 0 & 1 & 0 & 1 & 1 & 1 & 0 & 0 & 1 & 1 & 1 & 1 & 1 & 0 & 0 & 0 & 0 & 0 & 0 & 1 & 1 & 1 & 1 & 0 & 0 & 0 & 0 & 0 & 0 & 0 & 0 & 4 & 1 & 0 \\
\hline $\mathrm{R}_{2}$ & 0 & 0 & 0 & 1 & 0 & 0 & 1 & 0 & 0 & 0 & 0 & 0 & 0 & 0 & 0 & 1 & 1 & 0 & 0 & 0 & 0 & 0 & 0 & 1 & 1 & 1 & 0 & 1 & 0 & 1 & 0 & 1 & 0 & 1 & 1 & 0 \\
\hline $\mathrm{R}_{3}$ & 0 & 0 & 0 & 1 & 0 & 0 & 0 & 0 & 0 & 0 & 0 & 0 & 0 & 0 & 1 & 0 & 0 & 0 & 0 & 0 & 0 & 0 & 0 & 0 & 0 & 0 & 0 & 1 & 0 & 1 & 0 & 1 & 1 & 1 & 1 & 1 \\
\hline $\mathrm{R}_{4}$ & 0 & 0 & 0 & 0 & 0 & 1 & 1 & 1 & 0 & 0 & . & 1 & 1 & 1 & 0 & 0 & 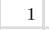 & 1 & 0 & 0 & 0 & 1 & 0 & 1 & 0 & 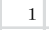 & 0 & 0 & 0 & 0 & 0 & 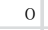 & 1 & 1 & 1 & 1 \\
\hline $\mathrm{R}_{5}$ & 0 & 0 & 0 & 0 & 0 & 0 & 0 & 0 & 0 & 0 & 0 & 0 & 0 & 0 & 0 & 0 & 0 & 0 & 0 & 0 & 0 & 0 & 0 & 0 & 0 & 0 & 0 & 0 & 0 & 0 & 0 & 0 & 1 & 0 & 0 & 1 \\
\hline $\mathrm{R}_{6}$ & 0 & 0 & 0 & 0 & 0 & 0 & 1 & 1 & 0 & 0 & 0 & o & 0 & 0 & 0 & 0 & 0 & 0 & 0 & 0 & 0 & 0 & 0 & 0 & 0 & 0 & 0 & 0 & 0 & 0 & 0 & 0 & 1 & 1 & 1 & 1 \\
\hline $\mathrm{R}_{7}$ & 0 & 0 & 0 & 0 & 0 & 0 & 0 & 1 & 0 & 0 & 0 & 0 & 0 & 0 & 0 & 0 & 0 & 0 & 1 & 0 & 0 & 0 & 0 & 0 & 0 & 0 & 0 & 0 & 0 & 0 & 0 & 0 & 1 & 1 & 1 & 1 \\
\hline $\mathrm{R}_{8}$ & 0 & 0 & 0 & 0 & 0 & 0 & 0 & 1 & 0 & 0 & 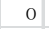 & 0 & 0 & 0 & 0 & 0 & 0 & 0 & 1 & 0 & 0 & 0 & 0 & 0 & 0 & 0 & 0 & 0 & 0 & 0 & 0 & 0 & 1 & 1 & 1 & 1 \\
\hline $\mathrm{R}_{9}$ & 0 & 0 & 0 & 0 & 0 & 0 & 0 & 1 & 0 & 0 & 0 & o & 0 & o & 0 & 0 & 0 & 0 & 1 & 0 & 0 & 0 & 0 & 0 & 0 & 0 & 0 & 0 & 0 & 0 & 0 & 0 & 0 & 1 & 0 & 0 \\
\hline $\mathrm{R}_{10}$ & 0 & 0 & 0 & 0 & 0 & 0 & 0 & 0 & 0 & 0 & 0 & 0 & 0 & 0 & 0 & 0 & 0 & 0 & 0 & 0 & 0 & 0 & 0 & 0 & 0 & 0 & 0 & 0 & 0 & 0 & 0 & 0 & 0 & 1 & 1 & 0 \\
\hline $\mathrm{R}_{11}$ & 0 & 0 & 0 & 0 & 0 & 0 & 0 & 0 & 0 & 0 & 0 & 0 & 0 & 0 & 1 & 0 & 0 & 0 & 1 & 0 & 0 & 0 & 0 & 0 & 0 & 0 & 0 & 0 & 0 & 0 & 0 & 0 & 1 & 1 & 1 & 1 \\
\hline $\mathrm{R}_{12}$ & 0 & 0 & 0 & 0 & 0 & 0 & 0 & 0 & 0 & 0 & 0 & 0 & 1 & 0 & 1 & 0 & 0 & 0 & 0 & o & 0 & 0 & 0 & 0 & 0 & 0 & 0 & 0 & 0 & 0 & 0 & 0 & 0 & 1 & 1 & 0 \\
\hline $\mathrm{R}_{13}$ & 0 & 0 & 0 & 0 & 0 & 0 & 0 & 0 & 0 & 0 & 0 & 0 & 0 & 0 & 1 & 0 & 0 & 0 & 0 & 0 & 0 & 0 & 0 & 0 & 0 & 0 & 0 & 0 & 0 & 0 & 0 & 0 & 0 & 1 & 0 & 0 \\
\hline $\mathrm{R}_{14}$ & 0 & 0 & 0 & 0 & 0 & 0 & 0 & 0 & 0 & 0 & 0 & 0 & 0 & 0 & 1 & 0 & o & 0 & 0 & 0 & 0 & 0 & 0 & 0 & 0 & 0 & 0 & 0 & 0 & 0 & 0 & 0 & 1 & 1 & 1 & 1 \\
\hline $\mathrm{R}_{15}$ & 0 & 0 & 0 & 0 & 0 & 0 & 0 & o & 0 & 0 & 0 & 0 & 0 & 0 & 0 & 0 & 0 & 0 & 1 & 0 & 0 & 0 & 0 & 0 & 0 & 0 & 0 & 0 & 0 & 0 & 0 & 0 & 1 & 1 & 1 & 1 \\
\hline$R_{16}$ & 0 & 0 & 0 & 0 & 0 & 0 & 0 & 0 & 0 & 0 & 0 & 0 & 0 & 0 & 1 & 0 & 0 & 0 & 0 & 0 & 0 & 0 & 0 & 0 & 0 & 0 & 0 & 0 & 0 & 0 & 0 & 0 & 1 & 1 & 1 & 1 \\
\hline $\mathrm{R}_{17}$ & 0 & 0 & 0 & 0 & 0 & 0 & 0 & 0 & 0 & 0 & 0 & 0 & 0 & 0 & 0 & 0 & 0 & 0 & 1 & 0 & 1 & 0 & 0 & 0 & 0 & 0 & 0 & 0 & 0 & 0 & 0 & 0 & 1 & 1 & 1 & 1 \\
\hline $\mathrm{R}_{18}$ & 0 & 0 & 0 & 0 & 0 & 0 & 0 & o & 0 & 0 & 0 & 0 & 0 & o & 0 & 0 & o & 0 & 1 & 0 & 0 & 0 & 0 & 0 & o & 0 & 0 & 0 & 0 & 0 & 0 & 0 & 0 & 0 & 0 & 0 \\
\hline $\mathrm{R}_{19}$ & 0 & 0 & 0 & 0 & 0 & 0 & o & 0 & o & 0 & 0 & 0 & 0 & 0 & o & 0 & 0 & 0 & 0 & 0 & 0 & 0 & 0 & o & 0 & 0 & 0 & 0 & 0 & 0 & 0 & o & 1 & 1 & 1 & 1 \\
\hline $\mathrm{R}_{20}$ & 0 & 0 & 0 & 0 & 0 & 0 & 0 & 0 & 0 & 0 & 0 & 0 & 0 & 0 & 0 & 0 & 0 & 0 & 1 & 0 & 0 & 0 & 0 & 0 & 0 & 0 & 0 & 0 & 0 & 0 & 0 & 0 & 0 & 0 & 0 & 0 \\
\hline $\mathrm{R}_{21}$ & 0 & 0 & 0 & 0 & 0 & 0 & 0 & 0 & 0 & 0 & 0 & 0 & 0 & 0 & 0 & 0 & 0 & 0 & 1 & 0 & 0 & 0 & 0 & 0 & 0 & 0 & 0 & 0 & 0 & 0 & 0 & 0 & 0 & 0 & 1 & 0 \\
\hline $\mathrm{R}_{22}$ & 0 & 0 & 0 & 0 & 0 & 0 & 0 & 0 & 0 & 0 & 0 & 0 & 0 & 0 & 0 & 0 & 0 & 0 & 0 & 0 & 0 & 0 & 0 & 1 & 0 & 0 & 0 & 0 & 0 & 0 & 0 & 0 & 0 & 1 & 1 & 0 \\
\hline $\mathrm{R}_{23}$ & 0 & 0 & 0 & 0 & 0 & 0 & 0 & 0 & 0 & 0 & 0 & 0 & 0 & 0 & 0 & 0 & 0 & 0 & 0 & 0 & 0 & 0 & 0 & 0 & 0 & 0 & 0 & 0 & 0 & 0 & 0 & 0 & 1 & 1 & 1 & 1 \\
\hline $\mathrm{R}_{24}$ & 0 & 0 & 0 & 0 & 0 & 0 & 0 & 0 & 0 & 0 & 0 & 0 & 0 & 0 & 0 & 0 & 0 & 0 & 0 & 0 & 0 & 0 & 0 & 0 & 0 & 0 & 0 & 0 & 0 & 0 & 0 & 0 & 1 & 1 & 1 & 1 \\
\hline $\mathrm{R}_{25}$ & 0 & 0 & 0 & 0 & 0 & 0 & 0 & 0 & 0 & 0 & 0 & 0 & 0 & 0 & 0 & 0 & 0 & 0 & 0 & 0 & 0 & 0 & 0 & 1 & 0 & 0 & 0 & 0 & 0 & 0 & 0 & 0 & 1 & 1 & 1 & 1 \\
\hline $\mathrm{R}_{26}$ & 0 & 0 & 0 & 0 & 0 & 0 & 0 & 0 & 0 & 0 & 0 & 0 & 0 & 0 & 0 & 0 & 0 & 0 & 0 & 0 & 0 & 0 & 0 & 0 & 0 & 0 & 0 & 0 & 0 & 0 & 0 & 0 & 1 & 1 & 1 & 1 \\
\hline$R_{27}$ & 0 & 0 & 0 & 0 & 0 & 0 & 0 & 0 & 0 & 0 & 0 & 0 & 0 & 0 & 0 & 0 & 0 & 0 & 0 & 0 & 0 & 0 & 0 & 0 & 0 & 1 & 0 & 0 & 0 & 0 & 0 & 0 & 0 & 1 & 1 & 1 \\
\hline $\mathrm{R}_{28}$ & 0 & 0 & 0 & 0 & 0 & 1 & 1 & 1 & 0 & 0 & 1 & 0 & 1 & 1 & 0 & 1 & 1 & 0 & 1 & 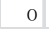 & 1 & 1 & 1 & 1 & 1 & 1 & 0 & 0 & 0 & 0 & 0 & 0 & 0 & 1 & 0 & 0 \\
\hline $\mathrm{R}_{29}$ & 0 & 0 & 0 & 0 & 0 & 1 & 1 & 0 & 1 & 0 & 1 & 0 & 1 & 1 & 1 & 1 & 1 & 0 & 0 & 0 & 0 & 1 & 0 & 1 & 0 & 1 & 0 & 0 & 0 & 0 & 0 & 0 & 0 & 1 & 0 & 0 \\
\hline $\mathrm{R}_{30}$ & 0 & 0 & 0 & 0 & 0 & 1 & 1 & 1 & 0 & 1 & 1 & 0 & 1 & 1 & 1 & 1 & 1 & 1 & 1 & 1 & 0 & 1 & 1 & 1 & 1 & 1 & 0 & 1 & 1 & 0 & 1 & 1 & 1 & 1 & 1 & 1 \\
\hline $\mathrm{R}_{31}$ & 0 & 0 & 0 & 0 & 1 & 1 & 1 & 0 & 1 & 1 & 1 & 0 & 1 & 1 & 1 & 1 & 1 & 1 & 1 & 1 & 1 & 1 & 1 & 1 & 1 & 1 & 1 & 1 & 1 & 1 & 0 & 1 & 0 & 0 & 0 & 0 \\
\hline $\mathrm{R}_{32}$ & 0 & 0 & 0 & 0 & 0 & 0 & 0 & 0 & 0 & 1 & 1 & 0 & 1 & 1 & 0 & 0 & 0 & 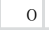 & 0 & 0 & 1 & 0 & 0 & 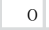 & 0 & 0 & 1 & 0 & 0 & 0 & 0 & 0 & 1 & 1 & 1 & 1 \\
\hline $\mathrm{R}_{33}$ & 0 & 0 & 0 & 0 & 0 & 0 & 0 & 0 & 0 & 0 & 0 & 0 & 0 & 0 & 0 & 0 & 0 & 0 & 0 & 0 & 0 & 0 & 0 & 0 & 0 & 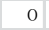 & 0 & 0 & 0 & 0 & 0 & 0 & 0 & 0 & 0 & 0 \\
\hline $\mathrm{R}_{34}$ & 0 & 0 & 0 & 0 & 0 & 0 & 0 & 0 & 0 & 0 & 0 & 0 & 0 & 0 & 0 & 0 & 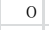 & 0 & 0 & 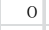 & 0 & 0 & 0 & 0 & 0 & 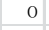 & 0 & 0 & 0 & 0 & 0 & 0 & 0 & 0 & 0 & 0 \\
\hline $\mathrm{R}_{35}$ & 0 & 0 & 0 & 0 & 0 & 0 & 0 & 0 & 0 & 0 & 0 & 0 & 0 & 0 & 0 & 0 & 0 & 0 & 0 & 0 & 0 & 0 & 0 & 0 & 0 & 0 & 0 & 0 & 0 & 0 & 0 & 0 & 1 & 0 & 1 & 1 \\
\hline $\mathrm{R}_{3}$ & 0 & 0 & 0 & 0 & 0 & 0 & 0 & 0 & 0 & 0 & 0 & 0 & 0 & 0 & 0 & 0 & 0 & 0 & 0 & 0 & 0 & 0 & 0 & 0 & 0 & 0 & 0 & 0 & 0 & 0 & 0 & 0 & 0 & 0 & 0 & 0 \\
\hline
\end{tabular}

Tab.3 Reachability matrix $M$

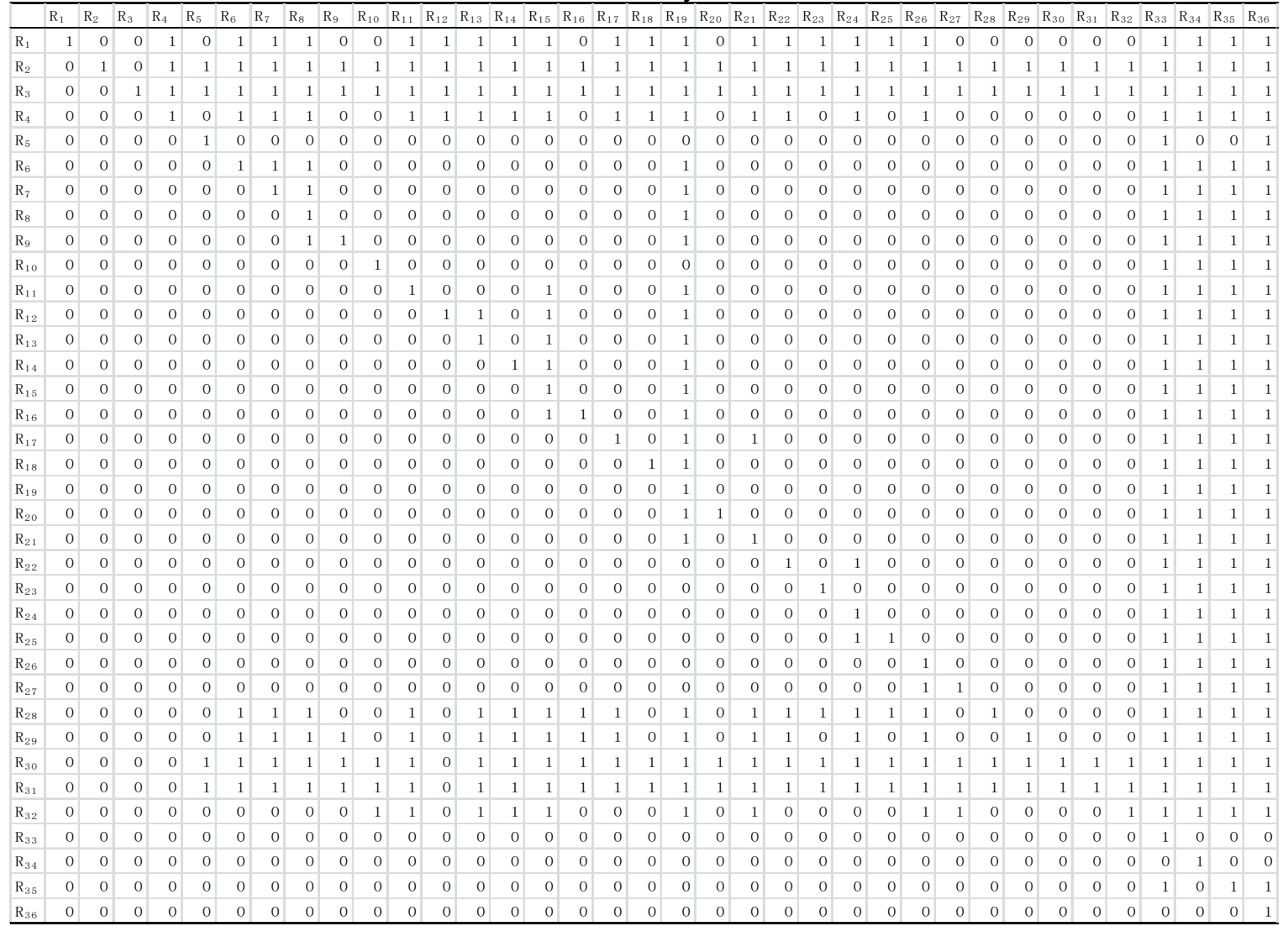


Tab.4 Hierarchical division of Reachability matrix $\mathrm{M}$

\begin{tabular}{|c|c|c|c|c|c|c|c|c|c|c|c|c|c|c|c|c|c|c|c|c|c|c|c|c|c|c|c|c|c|c|c|c|c|c|c|c|c|}
\hline & & & & & & & & & & & & & & & & & & & & & & & & & & & & & & & & & & & & $4 \mathrm{H}$ & \\
\hline & $\mathrm{R}_{1}$ & 1 & 0 & 0 & 1 & 0 & 0 & 0 & 0 & 0 & 1 & 1 & 0 & 1 & 0 & 1 & 1 & 1 & 0 & - & 1 & 1 & 1 & 0 & 1 & 1 & 1 & 0 & 0 & 1 & 1 & 1 & 1 & 1 & 1 & 1 & \\
\hline & $\mathrm{R}_{2}$ & 0 & 1 & 0 & 1 & 1 & 1 & 1 & 1 & 1 & 1 & 1 & 1 & 1 & 1 & & 1 & & 1 & & & & & & & & & & & & & & & & & & \\
\hline & $R$ & 0 & 0 & 1 & 1 & 1 & 1 & 1 & & 1 & & 1 & 1 & 1 & 1 & 1 & 1 & & 1 & & & & & & & & & & & 1 & & 1 & & 1 & & & \\
\hline & $\mathrm{R}_{\mathrm{R}}$ & 0 & & 0 & 1 & 0 & 0 & 0 & 0 & 0 & 1 & 1 & 0 & 1 & 0 & 1 & 1 & & 0 & & 1 & & & & & & & 0 & & 1 & & 1 & & 1 & & & \\
\hline & $\mathrm{R}_{30}$ & & 0 & & 0 & 1 & 1 & 1 & 1 & 1 & & 0 & 1 & 1 & 1 & & & & 1 & & 1 & & & & & & & & & & & 1 & & 1 & & & \\
\hline \multirow[t]{3}{*}{8} & $\mathrm{R}_{31}$ & 0 & 0 & 0 & $\underline{0}$ & 1 & & 1 & 1 & 1 & 1 & 0 & 1 & 1 & 1 & 1 & 1 & & 1 & & 1 & 1 & & 1 & & 1 & & 1 & & 1 & & 1 & 1 & 1 & 1 & 1 & \\
\hline & $R_{5}$ & 0 & 0 & 0 & 0 & 0 & 0 & 1 & 0 & 0 & 0 & 0 & 0 & 0 & 0 & & 0 & & 0 & & 0 & 0 & & 0 & & 0 & & 0 & & 0 & & & 0 & & & 0 & \\
\hline & $\mathrm{R}_{2}$ & 0 & 0 & 0 & 0 & 0 & 0 & 0 & & 0 & 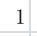 & 0 & 0 & 1 & 0 & & 1 & & 1 & & 1 & & & & & & & & & & & & & & & & \\
\hline & $\mathrm{R}_{29}$ & 0 & 0 & 0 & 0 & 0 & 0 & 0 & 0 & & 1 & 0 & 0 & 1 & 1 & 1 & 1 & & 1 & & 1 & & & & & & & & & & & & & & & & \\
\hline & $R_{6}$ & 0 & 0 & 0 & 0 & 0 & 0 & 0 & 0 & 0 & 1 & 0 & 0 & 1 & 0 & 0 & 0 & 0 & 0 & & 1 & 0 & 0 & 0 & 0 & 0 & (0 & 0 & & 1 & & 0 & 0 & 1 & & 1 & \\
\hline & $\mathrm{R}_{1}$ & & 0 & 0 & 0 & 0 & 0 & 0 & 0 & 0 & 0 & 1 & 0 & 0 & 0 & 0 & 1 & 0 & 0 & & 0 & & & 0 & 0 & 0 & & 0 & & 1 & & 0 & 0 & 1 & & 1 & \\
\hline & & 0 & 0 & 0 & 0 & 0 & 0 & 0 & 0 & 0 & 0 & 0 & 1 & 0 & 0 & 1 & 1 & 1 & 0 & & 0 & 1 & 0 & 0 & & 0 & & 1 & & 1 & & 0 & & 1 & & 1 & \\
\hline & $\mathrm{R}_{7}$ & 0 & 0 & 0 & 0 & 0 & 0 & 0 & 0 & 0 & 0 & 0 & 0 & 1 & 0 & & 0 & & 0 & & & & & 0 & & 0 & & & & & & 0 & & 1 & & & \\
\hline & $R_{g}$ & & 0 & & 0 & 0 & 0 & 0 & ( & 0 & & 0 & 0 & & & & 0 & & 0 & & & & & & & & & & & & & & & & & & \\
\hline & $R_{1}$ & 0 & 0 & 0 & 0 & 0 & 0 & 0 & 0 & 0 & 0 & 0 & 0 & c & 0 & & ( & & 0 & & & & & & & & & & & & & & & & & & \\
\hline & $\mathrm{R}_{1}$ & 0 & 0 & 0 & 0 & 0 & 0 & 0 & 0 & 0 & 0 & 0 & 0 & 0 & 0 & 0 & 1 & & 0 & & & & & 0 & & 0 & & 0 & & 1 & & 0 & 0 & & & 1 & \\
\hline & $\mathrm{R}_{\mathrm{t}}$ & 0 & 0 & 0 & 0 & 0 & 0 & 0 & 0 & 0 & 0 & 0 & 0 & 0 & 0 & & 0 & & 0 & & & & & 0 & & 0 & & 0 & & 1 & & 0 & 0 & 1 & & & \\
\hline & $R_{1}$ & 0 & 0 & 0 & 0 & 0 & 0 & 0 & 0 & 0 & 0 & 0 & 0 & 0 & 0 & & 0 & & 1 & & & & & 0 & & 0 & & & & & & 0 & & 1 & & & \\
\hline & $\mathbb{R}_{17}$ & 0 & 0 & 0 & 0 & 0 & 0 & 0 & 0 & 0 & 0 & 0 & 0 & 0 & 0 & $\underline{0}$ & 0 & & 0 & & & & $\underline{0}$ & 0 & & 0 & & 0 & & & & 0 & & 1 & & 1 & \\
\hline & $\mathrm{R}_{8}$ & & 0 & 0 & 0 & 0 & 0 & 0 & & 0 & & 0 & 0 & c & 0 & & 0 & & 0 & & & & & & & & & 0 & & & & & & & & & \\
\hline & $\mathrm{R}_{1}$ & & 0 & 0 & 0 & 0 & 0 & 0 & & 0 & & 0 & 0 & 0 & 0 & & 0 & & 0 & & & & & & & C & & 0 & & & & 0 & & & & & \\
\hline & $\mathrm{R}_{1}$ & 0 & 0 & 0 & 0 & 0 & 0 & 0 & 0 & 0 & 0 & 0 & 0 & 0 & 0 & & 0 & & 0 & & & & & & & 0 & & 0 & & & & 0 & & & & & \\
\hline & $\mathrm{R}_{2}$ & 0 & 0 & 0 & 0 & 0 & 0 & 0 & 0 & 0 & & 0 & 0 & 0 & 0 & & 0 & & 0 & & & & & & & & & & & & & 0 & & & & & \\
\hline & $\mathrm{R}_{2}$ & 0 & 0 & 0 & 0 & 0 & 0 & 0 & & 0 & & 0 & 0 & c & 0 & & 0 & & 0 & & & & & & & C & & 0 & & & & 0 & 0 & I & & 1 & \\
\hline & $\mathrm{R}_{2}$ & & 0 & 0 & 0 & 0 & 0 & 0 & & 0 & & c & & c & 0 & & 0 & & 0 & & & & & & & & & & & & & 1 & & & & & \\
\hline & & c & 0 & & 0 & 0 & 0 & 0 & & 0 & & c & & c & & & 0 & & 0 & & & & & & & & & & & & & & & & & & \\
\hline & & 0 & 0 & 0 & 0 & 0 & 0 & 0 & & 0 & & 0 & 0 & 0 & 0 & & 0 & & 0 & & & & & & & & & & & & & 0 & & & & & \\
\hline & & 0 & 0 & 0 & 0 & 0 & 0 & 0 & 0 & 0 & 0 & 0 & 0 & 0 & 0 & 0 & 0 & 0 & 0 & & 0 & 0 & C & 0 & 0 & 0 & & 0 & & 0 & & 0 & 0 & 1 & & 1 & \\
\hline & $R_{1}$ & 0 & 0 & 0 & 0 & 0 & 0 & 0 & 0 & 0 & 0 & 0 & 0 & 0 & 0 & 0 & 0 & & 0 & & 0 & 0 & 0 & 0 & 0 & 0 & & 0 & & 1 & 0 & 0 & 0 & 1 & & 1 & \\
\hline & & c & 0 & 0 & 0 & 0 & 0 & 0 & & 0 & & $c$ & & 0 & & & & & ( & & & & & & & & & & & & & 0 & 0 & & & & \\
\hline & $\mathrm{R}_{2}$ & 0 & 0 & & 0 & 0 & c & 0 & & 0 & & 0 & & c & 0 & & 0 & & 0 & & 0 & & & & & 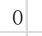 & & & & & & 1 & 0 & & & & \\
\hline & & c & 0 & & 0 & 0 & 0 & 0 & & 0 & & c & & c & & & 0 & & 0 & & ( & & & & & & & & & 0 & & & & 1 & & & \\
\hline & N & 0 & 0 & 0 & 0 & 0 & 0 & 0 & & 0 & & c & & c & & & & & 0 & & & & & & & & & & & 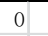 & & 0 & 0 & & & & \\
\hline & $R$ & 0 & 0 & 0 & 0 & 0 & 0 & 0 & & 0 & & c & & c & & & & & 0 & & & & & & & & & & & & & 0 & & & & & \\
\hline & & 0 & 0 & 0 & 0 & 0 & 0 & 0 & & 0 & & 0 & 0 & & 0 & & & & & & & & & & & 0 & & 0 & & 0 & & 0 & 0 & & 0 & D & \\
\hline & & & & & & & & & & & & & & & & & & & & & & & & & & & & & & & & & & & & & \\
\hline
\end{tabular}

\section{Interpretive structure model(ISM) of risk factors}

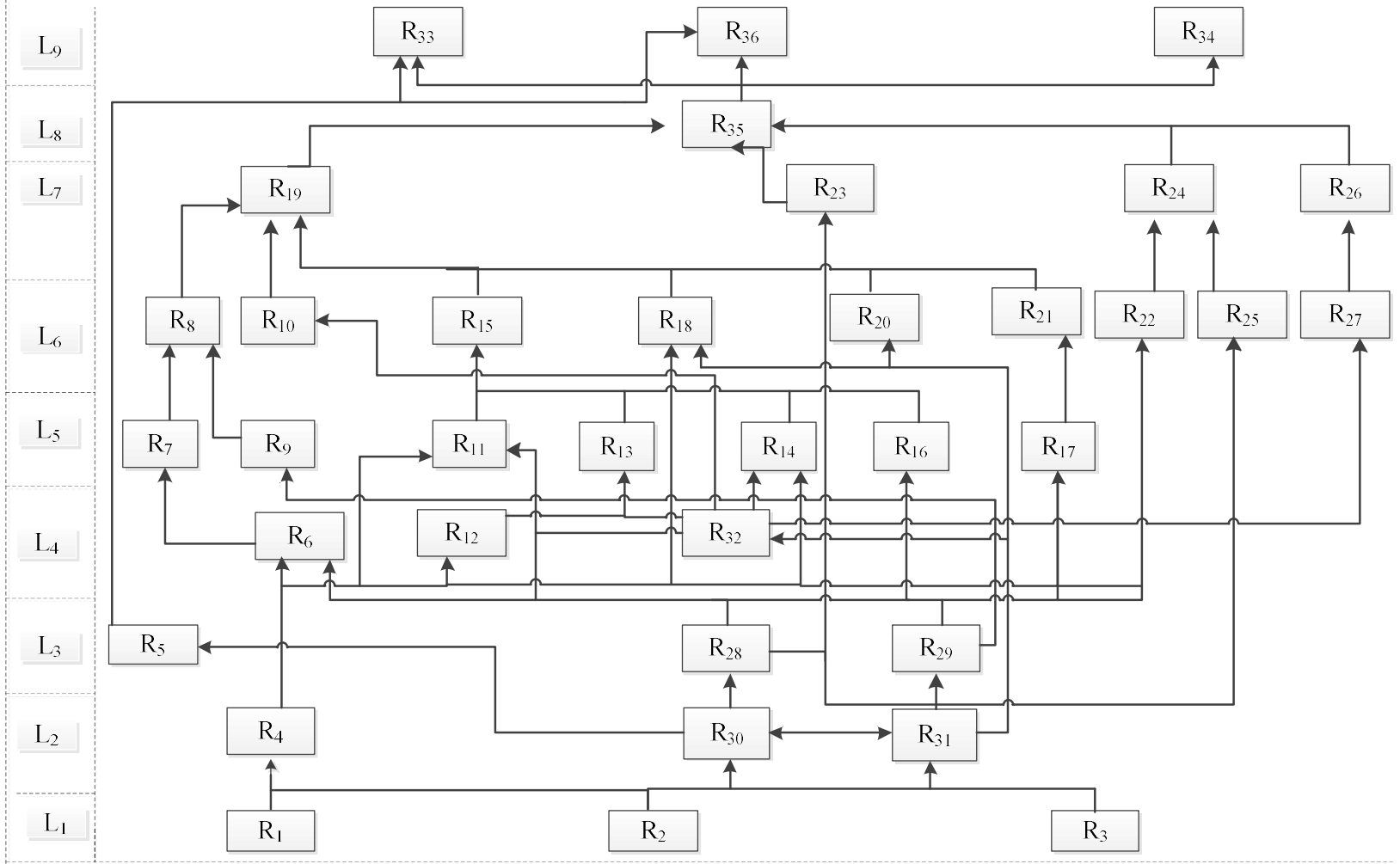

Fig 3. Interpretative structural model of construction risk factors of tunnel crossing bridge project 


\section{The judgment of the relationship between the risk factors of the project and the suggestion to deal with the risk management}

According to the interpretation structure model of the risk system of the tunnel under the existing bridge by using the active underpinning technology, we can see that the 36 risk factors can be divided into nine levels. Among them, the risk of L1 and L2 layer can be summarized into the environmental risks during the construction of the project, including the three risks of R1 adverse geological conditions and R2 adverse climatic environment, R3 earthquake risk are determined by the natural conditions of the project, the project belongs to the external environment risk; R31 personnel quality risk and R30 site organization management risk are the management risk source of the project, which belongs to the project's internal environmental risk; Risk R4 design for the environment risk of the project, also can be collected into the internal environment of project risk. The environmental risk is the risk of the project process, will have an impact on the construction of the project in each stage, but with the change of the progress of the project and the internal and external environmental conditions, these risk factors will be changed, therefore, for these risk factors should be analyzed from the dynamic point of view.In addition, environmental risk is the root cause of all kinds of risk events in project construction. Therefore, these risk factors should also be taken as the key content of risk management, especially the internal environmental risk of projects.

Risk at Layer L3 about R28 Construction Monitoring Risk, R29 Material Risk and R5 Information Communication Risk also fall into the overall process risk of the project. these risk factors affected the project internal and external environmental factors, but also have a direct impact on the risk in the process of project construction, the project is a concrete manifestation of the internal environment risk.Construction monitoring is an important part of project construction, and its risk should also be the key content of risk management. Material risk and information communication risk can be circumvented by internal environmental risk management.

The various risks of L4 to L7 belong to the stage risk of the project, which occurs with the implementation of active underpinning technology and different stages of tunnel construction. these risks by project internal and external environmental factors, is a result of the combined action of various risk source and technology solutions. For the management of stage risk, on the one hand, we must do well in the analysis and demonstration of the technical plan, choose the reasonable construction plan, and strengthen the management of the internal environment risk on the other hand, so as to avoid the occurrence of all risk events.

The R33 time risk, 34 security risk, R36 investment risk and R35 environmental risk of L9 and L8 layer are the results of various kinds of risks during the project construction process.In all kinds of results, the environmental risk result should cooperate with construction monitoring to do well in controlling this risk which the impact of project construction on existing bridges .

\section{Conclusion}

For the tunnel crossing existing bridge projects with active underpinning technology, the construction technology of the project is very difficult and the risk factors are numerous, by using interpretative structural model, identified the relationship between all risk factors, establishing the adjacency matrix, solving the reachability matrix and carry out the hierarchical division, it is helpful to clarify the relationship between risk factors and identify the key risk factors, It lays the foundation for the realization of the dynamic risk management of the project construction.

\section{Acknowledgements}

This work was financially supported by the National Natural Science Foundation (5176080030), National Natural Science Foundation (51668037). 


\section{References}

[1] Bu Jianqing. Research on the Methodology and Its Application of Active-underpinning for Bridge Piers under the Moving Trains [D].Beijing: China Academy of Railway Science,2010

[2] Jiang Xiaorui, Jia Xiaobo. Research on risk assessment in design stage of Open - cut tunnel of Guaihui inter-city railway through Guangshen highway bridge [J].Journal of Shijiazhuang Tiedao University(Natural Science Edition). 2013 (S2): 46-51

[3] Chen Jiejin, Zhang Yongjie. Quantitative risk assessment model of tunnel construction under passing existing bridges[J]. Journal of Central South University (Science and Technology), 2015(5) : 1862-1868

[4] CUI Yanghua. Safety risk assessment and control of road crossing the existing bridge of rail transit engineering [J]. Technology Innovation and Application: 2016(18): 219-221

[5] LIN Zhen. Risk Assessment of Metro Tunnel Under-passing the Existing Bridge Based on Fuzzy Fault Tree Analysis Method [J]. Fujian Architecture \& Construction. 2017(1):97-101

[6] WANG Lin, ZHOU Shi-jun. Research on risk factors analysis of synchronous construction technology of beam and pylon based on interpretive structural model [J]. Journal of Highway and Transportation Research and Development, 2015(2):100-107 